\title{
Writing on the Left: The Remarkable Career of Edna Ocko
}

\author{
Lynn Garafola
}

I first met Edna Ocko in the early 1980s. She was my mother-in-law's best friend from college days, someone who wrote about dance in the 1930s and took a dim view of critics since. My husband was a little in awe of Edna, and the first time she came to the house, I was told to cook an extra pound of pasta because Edna was coming. To my amazement, she was almost as tiny as my grandmother. We had a lot of pasta left over.

Edna Ocko, or Edna Meyers, as we knew her, was a formidable woman. She had been a communist in the 1930s and remained at heart a member of the Party, bonded by decades of friendship to the comrades-in-arms of her youth. She was punchy and articulate, with strong opinions and political convictions that never wavered even when she was named as a communist by Jerome Robbins before the House Un-American Activities Committee in 1953. She was also a first-rate dance critic who knew the difference between art and propaganda, could tell good choreography from bad, and wrote with verve. She was a crack editor, with a nose for a story, who understood intuitively how to balance different voices and views: unsurprisingly, her best days as a dance journalist coincided with the Popular Front, which embraced liberals and leftists alike. Finally, she was an intellectual, curious, well read, stimulated by ideas, who counted even balletomanes like Lincoln Kirstein among her colleagues.

In 1993 I did a public interview with Edna for the Society of Dance History Scholars conference "Of, By, and For the People." She was eighty-five and nervous about appearing in public, so to allay her fears and also to familiarize myself with her life, I had two lengthy conversations with her at her home about two weeks prior to the conference. The conference interview was never taped. Luckily, I had the presence of mind to tape these preliminary conversations. What follows is largely based on this material.

Edna Ocko was born in New York City in 1908. Her father was a cigarmaker, an ardent left-winger, and an activist in one of the era's most progressive unions. She grew up in Harlem, where many immigrant Jews then lived. Her first contact with dance came when a friend of the family took her to a recital by Isadora Duncan, probably during World War I:

I was a little girl, and I was immediately taken by the music, which was very exciting to me, and, of course, I was taken by the flow of the dance. That was my first introduction to dance.

Lynn Garafola is a dance critic and historian. She writes regularly for Dance Magazine, The Nation, and other publications. She is author of Diaghilev's Ballets Russes (1989) and editor of several books, including The Diaries of Marius Petipa, José Limón: An Unfinished Memoir, and The Ballets Russes and Its World, as well as the book series Studies in Dance History. She curated the New-York Historical Society exhibition Dance for a City: Fifty Years of the New York City Ballet. A former Getty Scholar, she teaches dance history at Barnard College. 
Music was Edna's entry into the dance field. While still a student at Lydia Wadleigh High School, she began to play for Sophie Berensohn and Mathilda Naaman, pupils of Bird Larson. She took her pay in the form of dance classes. She "studied everything," except ballet. "Dancers liked me to be their accompanist because I understood the movements, so I could make up music that would be appropriate for the movement, and then I could get free lessons."

Edna entered Hunter College in 1925. She majored in English, joined poetry and music societies, and discovered Marx.

The left-wing was proselytizing. I remember they said why don't you read...The Communist Manifesto?...So I went to the 42nd Street library...I read it and I cried. I remember crying in the reading room; it was the most beautiful thing I had ever read...So that's how I got involved.

In 1929 Ocko graduated from Hunter with honors. She received a substitute teacher's license, and from 1930 to 1935 taught English in New York City high schools-a good job in those terrible years of the Depression. She continued to write and to play for dance classes. Then, in 1931, she began studying with Hanya Holm at the newly opened Mary Wigman school. She had a scholarship and no longer had to barter her services as an accompanist. She could be "serious" about dancing, and the experience gave new direction to her life. At the Wigman school she found students who shared her political sympathies, and with them she founded the New Dance Group in February 1932.

Their slogan was "The Dance is a Weapon," their goal to bring modern dance to the masses. Their first headquarters was a donated room in the Central Opera House (Anyon 1933, 4), and it was here that Edna, as a member of the group's Dance and Editorial Committees (Anyon 1933, 12), found her true calling.' "Basically, I was an organizer," she told me. The New Dance Group grew by leaps and bounds. Office workers, school teachers, shop workers, housewives, and college students poured into the organization, and within six months a "lay" group was formed. Meanwhile, working-class organizations in the "hinterlands" of Brooklyn, the Bronx, and Harlem kept up a continuous demand for performances at union halls and political rallies (Delman 1944, 8; Ocko 1934b, 29).

Teaching was a major activity. "Lessons for ten cents an hour, with a political discussion thrown in gratis," was how Edna later described the Group's classes (Ocko n.d., 1). Classes consisted of three hour-long sessions: one hour for technique, one for creative work on subject matter suggested by the Group's "Educational Committee," and one for a meeting that included "discussion of technical and political problems" (Ocko 1934b, 28). Intermediate and advanced students were eligible to join one of several performing groups, and anyone could propose an idea for a project to the Dance Committee. Leadership was collective. "There is no one dance choreographer, or director," Edna told readers of New Theatre in 1934 (Ocko 1934b, 28). The Group sponsored social activities, including membership meetings with folk dancing, and lectures on subjects like the origin of the revolutionary dance, and even a children's section (Delman 1944, 8; Anyon 1933, 5). Any technique was acceptable. "Within six months we began to teach tap dancing and ballet. Anna Sokolow started a group and taught Graham technique. Then we had someone...teaching Duncan....We taught whatever a teacher was willing to teach." The Group also sent teachers out to trade unions. "It was part of our 
beliefs," said Edna, "that the masses have a right to culture, that the proletariat has a right to the best of culture, and we thought we were the best of culture."

With the founding of the Workers Dance League late in 1932, the radical dance movement acquired an organizational structure. Early members of the League included the New Dance Group, Harlem Dance Group, and Red Dancers, several union-sponsored groups, groups sponsored by recreational organizations (Nature Friends Dance Group), and youth groups (Junior Red Dancers and American Youth Federation Dance Group) (Gordon 1933, 6). Later members included the New Duncan Group and the Modern Negro Dance Group, founded by Hemsley Winfield. In 1933 the League sponsored a National Spartakiad (Gordon 1933, 15), the first of several events that signaled its emergence as an influential New York presenter of modern dance. By 1935, with some fifty groups outside New York affiliated with the League (now renamed the New Dance League), "the workers' dance movement of New York," as Edna wrote in New Theatre, "[had become] a national movement."

Approximately a half million people attended dance recitals in the year 1934-1935. Of these, more than ninety per cent came to see New Dance League performances, or the New Dance League went to them....When one remembers that the modern dance has had, of all the arts, the most limited appeal, and therefore the most indifferent audience, these facts take on even more significance. (Sellars 1935, 7)

Edna was in the thick of it. "I organized a great many things. I organized organizations.... The Workers Dance League, the New Dance League-I was behind them." She was full of ideas. One was for a 1935 concert called "Men in The Dance" that was sponsored by the New Dance League and the magazine New Theatre, of which she was the dance editor. "We were really interested in men," a point borne out by the fact that the New Dance Group early on had a men's section (Ocko 1934b, 28). "And...there were men in the dance. We had José Limón, Charles Weidman and his group, Paul Draper, Bill [William] Dollar, Roger Pryor Dodge....[W]ith dancers like that, we had a program." Much to Edna's surprise the two performances sold out in the first couple of days. "It took me a long time to figure out why....Back then, we were very innocent about homosexuality."

The numbers were phenomenal. In December 1935, for a recital to benefit the International Labor Defense, "Carnegie Hall was packed to the rafters" (Skrip 1935b, 5). Earlier in the year, for a program of group and solo dances presented by the Workers Dance League at the Center Theatre for the benefit of The Daily Worker, "standing room was sold out for the first time in the history of Radio City" (Skrip 1935a, 5). No wonder Ralph Taylor, in reviewing the "Men in the Dance" concert for Louis Horst's Dance Observer, felt compelled to denounce the League's "total bankruptcy." "The 'New' Dance League," he wrote, "is nothing but a commercial concert agency which welcomes anyone and everyone providing they are willing to contribute their talent, time, and energy - gratis-to help garner the shekels for a "program against War, Fascism and Censorship"' (Taylor 1935, 64). In fact, the revolutionary dance movement represented a challenge to the hegemony of modern dance as this was exemplified by the Bennington School of the Dance, with its relatively privileged student body of college girls from Middle America and physical education teachers. The dance com- 
munity that Edna helped propel into being was heavily Jewish, with roots in New York's immigrant ghettos and ties to its avant-garde theater, music, and art communities.

In the 1930s the Communist Party was not a clandestine organization. Communists ran for office and were sometimes elected. Beginning in 1935, when the Party line shifted to the Popular Front, communists were encouraged to make common cause with liberals. The changing nomenclature of the Dance League reflects this political shift, as did the emphasis on antifascism, which largely supplanted the proletarian line of the early 1930s.

The left, Edna explains, was "a force" in the dance field "because it brought a receptive, enthusiastic audience to a dance world that was pretty effete and closed in on itself."

\begin{abstract}
At this time there was a big upsurge in the arts, and it was mainly connected with the fact that there was an audience for the arts that hadn't had access to them. This audience wouldn't go to the Guild Theatre, for instance, to see a dance recital by Martha Graham, but if we gave a concert at the Hippodrome, they came. Not only because we offered a broad spectrum of dancers, but because it was not expensive. The audience narrowed down when it became expensive; they couldn't afford it.
\end{abstract}

Early on, Edna realized that her usefulness to the dance field lay in activities other than performance. Her work as an organizer was an acknowledgment of this, as was the writing and editing that became increasingly important as the decade advanced. A selection of her essays and reviews, edited by Stacey Prickett, was published in 1994 (Prickett 1994), but this is only the tip of the iceberg. Edna was a prolific writer, publishing in both the left-wing and mainstream press, and she wrote under a half-dozen names-Edna Poe, Skrip, Elizabeth Skrip, Marion Sellars, Eve Stebbins, Frances Steuben. Even Edna Ocko, her maiden name, was something of a pseudonym, since in private life she used her married name, Edna Meyers. (She had married the musician, film critic, and documentary filmmaker Sidney Meyers in 1930.) What accounted for the multiple identities? "I really think...I adopted different names...so that I could go to the same recital more than once." Another reason, surely, must have been the problem of wearing so many hats simultaneously. If Edna was a mover-andshaker of the revolutionary dance movement, someone who made it happen, she was also its critic and public advocate. Editors were happy to look the other way. "[T]here was very little competition. I was literate; I was... able to talk a good line, and I was one of the few people who really knew the dance field."

Her writing was remarkably free of cant, and she was very clear about her loyalties:

My responsibility to the dance field was to make sure that the people who read... whatever magazine I was writing for developed a point of view that would be catholic, in the sense of being able to accept dances, if they were good, no matter what their content was....I was not unscrupulously partisan. I was more interested in good dancing. I felt that the proletariat deserved the best.... We were radical in the sense that we believed that change had to take place, that it shouldn't be commercial but had to be artistic.... We were generous, I think, toward the bad dancers in the field, if they had the right ideas, but we never praised them only for the right ideas. 
As a critic, Edna could be tough. Reviewing a Workers Dance League concert in 1934, she praised the organization for its "ability to appeal not only to thousands of workers and intellectuals, but actually to invoke continued encouragement and praise from bourgeois as well as proletarian critics." But she criticized the League for "expos[ing] itself to attack from all quarters if, either through lack of artistic forces or lack of self-imposed discipline, it permits a recital of the calibre of the first appearance of revolutionary dance groups this season....The recital was not only ill-advised artistically, but unfortunate from the technical end as well"'(Skrip 1934, 5).

Because she knew the field inside out, she knew that only a minority of the revolutionary dance groups were professional:

Groups like Edith Segal's Red Dancers were agit-prop groups. They were dancing because they liked to dance, but they were not professional dancers, whereas people in...the New Dance Group were all studying dancing someplace else-with Hanya Holm...or Martha Graham...[or] the HumphreyWeidman group. These were the more professional dancers; the dancers in Nature Friends and a lot of other groups studied dancing only with us....[T]hroughout the country there was the same split between amateur and more professional groups.

Edna often alluded to this split in her reviews. "As it now stands," she wrote in 1935,

only two groups, the New Dance Group, and the Theatre Union Dance Group, are creating dances that rightfully belong on the concert stage. The Red Dancers and the Nature Friends, while they are to be commended for their sincere efforts, are not only unsuited technically for recital work, but as a matter of fact are creating, not concert dances, but a commendable variety of agitprop dance.... On the concert platform,... where...a large part of the audience is composed of intellectual and bourgeois elements, these dances have neither subtlety of theme, nor richness of form to commend them, and the more developed dance audience finds these dances both crude and wearisome. (Ocko 1935, 25)

Edith Segal was Edna's bête noire. "I never publicly trounced Edith Segal," she told me, "but I knew she wasn't a good dancer; she was an agit-prop person." In fact, Edna was always critical of Segal. Of Black and White, one of Segal's most popular dances, Edna wrote:

Put any negro and white performer on the stage, show them struggling under similar conditions, show their initial enmity and their final heroic handclasp and fist salute, and you have ideal conditions for applause. Black and White, by the Red Dancers, recreates a slogan in pantomimic movement, but surely no one can claim for it an imaginative or original approach to the negro question, despite the fact that it evokes lusty applause. (Ocko 1935,25$)^{2}$ 
However much Edna applauded the sentiments, good propaganda was not automatically good art. $^{3}$

Still, she felt that the "infusion of revolutionary ideology" into modern dance was salutary. Unlike Martha Graham ${ }^{4}$ and other modern dancers of the early 1930s, the revolutionary dancers did not shy away from depicting the world around them. Rather they embraced it, finding in the turbulence and cruelty of contemporary life both a ready source of material and a new expressive content. Revolutionary ideology also prompted "valuable experimentation in form" (Skrip 1935a, 5). The use of improvisation as a choreographic tool was widespread. Music was abjured. Many dances were set to poems or had verbal accompaniment, a practice that anticipated by several years Martha Graham's innovative use of text in American Document.

In 1934 Edna became the dance editor of New Theatre, a left-wing monthly devoted to theater, dance, music, and film. She did some of her best writing for New Theatre, and built the dance pages into one of the magazine's liveliest sections and a force in the dance world. She had a stable of writers, including Edith Segal, Blanche Evan, Paul Love, and Mignon Verne, a founder of the New Duncan Dancers.

I couldn't disown the bad dancers, and I couldn't praise them. But if they wrote about other dancers or if they wrote about themselves, they would have articles in New Theatre.... Remember, people are very eager to put forward their point of view. So if they were asked to write about themselves-even if they had to do it for nothing, as they all did-they jumped at the chance.

Martha Graham and Doris Humphrey were among the many dancers and choreographers who contributed to New Theatre. "I asked them to talk about dancing. They didn't have to talk about the revolution." There were articles about wage scales for dancers (Mitchell 1937), men in the dance (Friedman and Lansky 1934), music for the dance (Siegmeister 1935), revolutionary dance forms (Ignatin 1935), and a surprisingly large number of articles about balletabout Massine by Irving Deakin (1936), the Fokine ballets by Blanche Evan (1935), Nijinsky's tragedy by Lydia Nadejina (1934), and any number of articles by Edna's most gifted "discovery"-Lincoln Kirstein.

She didn't remember when or how they met, but by October 1934 he was writing for her. His first article was "Revolutionary Ballet Forms," in which he asserted that "the destruction of the proscenium arch...the use of negroes in conjunction with white dancers, the replacement of an audience of snobs by a wide popular support are all part of Balanchine's articulate program" (Kirstein 1934) - a measure of how close Kirstein had drawn to the left. Other essays followed-"The Dance as Theatre" (1936a; in which he defended ballet against modern dance), "James Cagney" (1935b; in which he called the Hollywood tough "the best young male actor in America"), "A Museum of Ballet" (1935a; in which he criticized the de Basil Ballet Russe for failing to offer the "fresh and creative experience" of the old Diaghilev company), and "Dancing in Films" (1936b; in which he concluded that "The camera as an eye for dancing is as yet more unstudied than misunderstood"). These were not casual pieces of work, but articulated ideas that reappeared in Kirstein's work for decades.

For all their differences Edna and "Lincoln," as she always called him, had certain things in common. Both were young, and they were advocates, eager to get their ideas across to the 
public. They were also intellectuals. They read books and thought about them. Edna had an "encyclopedic knowledge of...dance, past and present," wrote New Theatre editor Herbert Kline $(1985,199)$ in a memoir. Kline may have found this daunting, but how it must have appealed to Kirstein. Like other left-wing intellectuals of the time, she read Hound and Horn, which he had founded, "because it had things to say about the arts [a]nd was...left of center." In November 1936 an unsigned notice in New Theatre announced that contrary to rumors and even "positive statements to the effect," it was not planning to "sponsor a dance magazine."

There is a definite and crying need for a magazine, international in scope, to deal with all phases of the art, and its interrelation with theatre and film. Such a magazine, to include translations and reprints of hitherto unavailable material, historical and analytical articles, illustrative material ranging from action photographs to stage designs for theatre dances, creative material including libretti and scripts of various sorts-in short, a periodical of permanent, rather than topical interest, modeled perhaps after the Archives Internationales de la Danse. ("Dance Quarterly" 1936)

The magazine was to be a quarterly, and Irving Deakin, Lincoln Kirstein, Paul Love, Paul Magriel, and Edna Ocko were mentioned as being members of the tentative editorial board. For the moment nothing came of their plans. The following year New Theatre folded, and in 1938, after a visit to the Soviet Union, Edna became the editor-in-chief of TAC, an arts monthly published by the Theatre Arts Committee. When this ceased publication in August 1940, Edna pretty much retired from the dance field. But in 1942 the magazine that she, Kirstein, and the others had dreamed of founding came to fruition with Dance Index. Except that now, with Edna gone and the first round of anti-Communist hearings underway, the politics associated with its gestation vanished. Dance Index would exist under the unofficial auspices of the Museum of Modern Art.

Edna kept a low profile in the late 1940s and early 1950s, when McCarthyism was decimating the left. By 1953 , when she was publicly named before HUAC by Jerome Robbins, ${ }^{6}$ she had been doing public relations work for the Albert Einstein College of Medicine and other educational and charitable institutions for a decade. She returned to school in 1957, earning a master's degree in remedial reading, a doctorate in counseling, and her New York State certification as a psychologist. She remained an intellectual of the left. Her dissertation was a study of "disadvantaged Negro boys," and she worked for more than twenty years at the Northside Center in Harlem, first as a reading specialist, then as chief psychologist. She taught at City College from 1967 to 1980 . $^{7}$

Edna mellowed with age. "You know, I separated my political leanings from my aesthetic feelings," she told me. "If they danced well, if they did something that was expressive, I liked them, regardless of whether they were politicalized or not." But she added, "they became political." Edna never lost her punch.

\section{Notes}

1. In the New Dance Group First Anniversary Recital program (p. 12) Ocko-as Edna Poe, one of her many pseudonyms-is listed as a member of both the Dance Committee and the Editorial Committee. 
2. From the start African-American students were welcomed at the New Dance League, according to Edna. However, they were a "minority." "There was really no prejudice.... The thinking around the Communist Party was very important for all of us who grew up wanting to be decent human beings."

3. Edna was even more critical of Segal's Tom Mooney, a solo "whose use of a poem was oversimplification to a point of crudity" (Ocko 1934c, 30). This was a review of a Workers Dance League recital of seven artists in revolutionary dance solos, presented under the auspices of New Theatre, at the Civic Repertory Theatre on November 25, 1934. For a more judicious appraisal of Segal's work, see Ellen Graff (1997, chap.2). For a charming memoir of Segal in the early 1980s, see Jowitt (1985).

4. On Graham's eschewal of the contemporary, see Ocko (1934a, 7).

5. In October 1935 and in November 1936 Sol Hurok took full-page advertisements in New Theatre for the Ballet Russe de Monte Carlo, a measure of how important he regarded the magazine's readership.

6. For a transcript of Robbins's testimony, see Bentley (1971, 625-634). For a discussion of this episode in Robbin's life, see Lawrence (2001, 199-211).

7. Most of this biographical information comes from Edna's résumé dated September 1980.

\section{Works Cited}

Anyon, Nell [pseud. of Nadia Chilkovsky]. 1933. "What is the New Dance Group?" In New Dance Group First Anniversary Recital program, March 26.

Bentley, Eric, ed. 1971. Thirty Years of Treason: Excerpts from Hearings before the House Committee on Un-American Activities, 1938-1968. New York: Viking.

“A Dance Quarterly?” 1936. New Theatre. (November): 28.

Deakin, Irving. 1936. "Massine.” New Theatre (November): 27-28.

Delman, Judith. 1944. "The New Dance Group.” Dance Observer (January).

Evan, Blanche. 1935. "The Fokine Ballets.” New Theatre. (September): 26.

Friedman, Ezra and Irving Lansky. 1934. "Men in the Modern Dance." New Theatre (June): 21.

Gordon, Midi. 1933. “The Workers Dance League." In New Dance Group First Anniversary Recital program, March 26.

Graff, Ellen. 1997. Stepping Left: Dance and Politics in New York City, 1928-1942. Durham, NC: Duke University Press.

Ignatin, Irving. 1935. “'Revolutionary' Dance Forms.” New Theatre (December): 28-29.

Jowitt, Deborah. 1985. "A Lifetime of Art on the Left" [Village Voice, July 6, 1982], 267-272. In The Dance in Mind: Profiles and Reviews 1976-83. Boston: David Godine.

Kirstein, Lincoln. 1934. "Revolutionary Ballet Forms." New Theatre (October): 14. . 1935a. "The Dance as Theatre." New Theatre (May): 20-22. . [under the pseud. Forrest Clark]. 1935b. "James Cagney." New Theatre (December): 14. . 1936a. "A Museum of Ballet." New Theatre. (June): 20-21ff. . 1936b. "Dancing in Films." New Theatre (September): 11-13. 
Kline, Herbert, ed. and commentary. 1985. New Theatre and Film 1934 to 1937: An Anthology.

Foreword by Arthur Knight. San Diego: CA: Harcourt Brace Jovanovich.

Lawrence, Greg. 2001. Dance with Demons: The Life of Jerome Robbins. New York: Putnam.

Mitchell, Louise. 1937. "Wage Scales for Dancers." New Theatre and Film (April): 32-33ff.

Nadejina, Lydia. 1934. "Nijinsky's Tragedy.” New Theatre (September): 27.

Ocko, Edna. n.d. "Of Leotards and Lenin.” Unpublished manuscript. Collection of Edna Ocko Meyers. .1934a. "Whither Martha Graham?" New Theatre (April). . 1934b. "The New Dance Group." New Theatre (November). . 1934c. "The Dance.” New Masses (December 4).

1935. "The Dance League Recital" [review of Workers Dance League concert, Town Hall, December 23, 1934]. New Theatre (February).

Prickett, Stacey, sel. and intro. 1994. "Reviewing on the Left: The Dance Criticism of Edna Ocko." In Of, By, and For the People: Dancing on the Left in the 1930s. Edited by Lynn Garafola, 65-103. Studies in Dance History 5, no. 1 (Spring).

Sellars, Marion [pseud. of Edna Ocko]. 1935. "The Revolutionary Dance Achieves a Mass Audience." Daily Worker (December 12).

Siegmeister, Elie. 1935. "Music for the Dance." New Theatre (October): 10-11ff.

Skrip, Elizabeth [pseud. of Edna Ocko]. 1934. "World of the Dance: Workers Dance League in Group Recital." Daily Worker (December 27). . 1935a. "World of the Dance: Outstanding Program by Dance League." Daily Worker (February 20). . 1935b. “Dance: A Notable Recital.” Daily Worker (December 19).

T[aylor], R[alph]. 1935. "Men in the Dance." Dance Observer (Summer). 